
053620190407

\title{
Nitrogen supply to arugula from pig slurry composts in contrasting soils
}

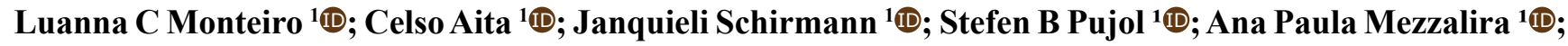 Kathleen da S Paust ${ }^{1} \mathbb{D}$; Cristian Mateus Freiberg ${ }^{1} \mathbb{D}$; Diego Antônio Giacomini ${ }^{1} \mathbb{D}$; Sandro José Giacomini ${ }^{1} \mathbb{D}$}

${ }^{1}$ Universidade Federal de Santa Maria (UFSM), Santa Maria-RS, Brasil; luannacorream@gmail.com; celsoaita@gmail.com (correspondent author); janquielis@gmail.com; pujolstefen@gmail.com; anapaulamezzalira@hotmail.com; kaatps@outlook.com; cristian.freiberg@gmail. com; agrogiacomini@gmail.com; sjgiacomini@gmail.com

\begin{abstract}
This study was developed to evaluate nitrogen $(\mathrm{N})$ supply to arugula from composts produced by automated composting of pig slurry (PS). During the composting process, retorted oil shale (ROS) and dicyandiamide (DCD) were added to PS to mitigate gaseous $\mathrm{N}$ losses. The study was developed in a greenhouse where four treatments were evaluated, three with compost addition (PS compost, PS compost + ROS, and PS compost + ROS + DCD) and one without compost (control) in two contrasting soils (clayey and sandy-loam). The best result was obtained with the compost without additives (PS compost), which increased the arugula dry matter yield 2.2 times in clayey soil and 6.1 times in sandy-loam soil compared to the control treatment. The presence of ROS in composts reduced arugula dry matter yield in $27 \%$ in clayey soil and $35 \%$ in sandyloam, while DCD did not affect arugula dry matter yield. The results of this study show that the addition of ROS to PS during composting reduces $\mathrm{N}$ supply to arugula, both in the immediate (first cut) and residual effect (second cut).
\end{abstract}

Keywords: Eruca sativa, automated composting, retorted oil shale, dicyandiamide.

\section{RESUMO}

Fornecimento de nitrogênio à rúcula por compostos de dejetos de suínos em solos com características contrastantes

O estudo foi desenvolvido para avaliar o fornecimento de nitrogênio $(\mathrm{N})$ à rúcula através de compostos obtidos por compostagem automatizada de dejetos líquidos de suínos (DLS). Durante a compostagem, xisto retortado (XR) e dicianodiamida (DCD) foram adicionados aos DLS para mitigar as perdas gasosas de N. O estudo foi realizado em casa de vegetação, com quatro tratamentos, sendo três com aplicação dos compostos (composto DLS, composto DLS + XR e composto DLS + XR + DCD) e um sem aplicação de composto (testemunha), em dois solos contrastantes [argiloso (Latossolo) e franco-arenoso (Argissolo)]. O melhor resultado foi obtido com o composto sem aditivos (composto DLS), o qual aumentou a produção de matéria seca da rúcula em 2,2 vezes no Latossolo e 6,1 vezes no Argissolo, comparado ao tratamento testemunha. A presença do XR nos compostos reduziu a produção de rúcula em $27 \%$ no Latossolo e em $35 \%$ no Argissolo, enquanto a presença de DCD não afetou a produção de matéria seca da rúcula. Os resultados deste estudo indicam que a adição de XR aos DLS durante a compostagem diminui o fornecimento de $\mathrm{N}$ à rúcula, tanto no efeito imediato $\left(1^{\circ}\right.$ corte $)$ quanto residual $\left(2^{\circ}\right.$ corte $)$.

Palavras chave: Eruca sativa, compostagem automatizada, xisto retortado, dicianodiamida.

\section{Received on January 29, 2019; accepted on October 2, 2019}

$\mathrm{I}^{\mathrm{s}}$ tensive pig farming generates a large volume of liquid manure, including mixing of feces, urine, food scraps, and water from the troughs and from the washing of the premises. While pig slurry (PS) contains nutrients to plants, improper use as a fertilizer can result in contamination of soil, air and water resources. Composting of PS is considered an important alternative for manure management, as it produces a stable, sanitized and nutrient-rich organic material (Bernal et al., 2017), which facilitates its use as organic fertilizer.

Automated composting consists of frequent PS applications on substrates with high $\mathrm{C} / \mathrm{N}$ ratio (Oliveira \& Higarashi, 2006). The application of PS and turning of the compost piles are done simultaneously with a machine, which provides reduction in labor. Therefore, it is possible to apply a larger volume of PS to substrates compared to traditional composting, where PS is added to the substrate at the beginning of the composting process (Oliveira, 2004). Because PS is added several times during composting, the final compost is likely to be rich in nitrogen, which improves its potential as nutrient source to crops.

There is a lack of researches investigating the agricultural use of composts obtained by automated composting of PS, as this process had been recently introduced in Brazil (Doneda, 2014). Using a dose of 18.4 $\mathrm{t} \mathrm{ha}^{-1}$ of the compost obtained by this process in lettuce, Cantú (2014) found $1.77 \mathrm{t} \mathrm{ha}^{-1}$ leaf dry matter yield in the first crop (immediate effect) and 1.62 
$\mathrm{t} \mathrm{ha}^{-1}$ in the second crop (residual effect) corresponding to an increase of 0.94 and $1.39 \mathrm{t} \mathrm{ha}^{-1}$ relative to the control, respectively. These yields are higher than those found by Parizotto \& Pandolfo (2009), which ranged from 0.25 to $0.75 \mathrm{tha}^{-1}$ with increasing doses $\left(0,10,20\right.$ and $\left.40 \mathrm{t} \mathrm{ha}^{-1}\right)$ of a compost obtained by traditional composting method. According to Cordovil et al. (2007), the yield of crops fertilized with composts is associated to compost $\mathrm{N}$ mineralization rate. Therefore, it is important to evaluate the $\mathrm{N}$ supply potential of the compost obtained with automated composting.

Although the use of automated composting has several advantages over traditional composting, as cited above, there are still doubts, especially in regard to the amount of $\mathrm{N}$ loss by ammonia $\left(\mathrm{NH}_{3}\right)$ volatilization and denitrification during the process. Several strategies have been evaluated to mitigate such losses, especially the use of additives during composting (Barthod et al., 2018), such as: acids (Doneda, 2014), zeolites (Giacomini et al., 2014) and retorted oil shale (Giacomini, 2017). Nitrogen loss by denitrification during composting can be reduced through the use of nitrification inhibitors, as demonstrated by Luo et al. (2013) with dicyandiamide (DCD), which inhibits the first step of the nitrification process. Luo et al. (2013) and Jiang et al. (2016) noted that the DCD addition during the composting process increases the $\mathrm{N}$ content in the final compost.

The effects of additives applied to the soil on microorganism's activity are known. Doumer et al. (2011) found that application of ROS to soil improved the soil microbial activity and did not reduce microbial biomass and also did not impact the soil enzymatic activity. Regarding DCD, Singh et al. (2008) did not observe adverse impact of DCD application on soil respiratory activity or microbial biomass. The same was observed by O'Callaghan et al. (2010) who found that DCD application to the soil did not change the diversity of the soil bacterial community. However, DCD could reduce the population size of ammonia-oxidising bacteria (O'Callaghan et al., 2010), the microbes targeted by DCD. According to our knowledge there are no studies evaluating the effect of the presence of these additives in the final compost on a soil microbiota.

There are several studies involving the use of additives to reduce $\mathrm{N}$ losses during composting (Barthod et al., 2018; Cáceres et al., 2018), but none have evaluated the effect of additives on the $\mathrm{N}$ supply potential of the compost to crops. Moreover, there is still no recommendation for specific application dose of composts produced by automated composting of PS. The use of inadequate doses may result in economic loss and environmental damage. This study aimed to evaluate how the addition of retorted oil shale and dicyandiamide to PS during automated composting affects $\mathrm{N}$ supply to arugula in two soils with contrasting characteristics.

\section{MATERIAL AND METHODS}

The soils were collected from the surface layer $(0-10 \mathrm{~cm}$ depth) of two experimental areas that were managed for more than 10 years under a no-till system in the state of Rio Grande do Sul, Southern Brazil. The clayey soil, classified as a Rhodic Hapludox (Soil Survey Staff, 2014), was collected at the experimental area of Fundacep/ CCGL, located in Cruz Alta-RS, Brazil (28 $\left.8^{\circ} 3^{\prime} \mathrm{S}, 53^{\circ} 40^{\prime} \mathrm{W}\right)$. The sandy-loam soil, classified as Typic Paleudalf (Soil Survey Staff, 2014), was collected at the experimental area of the Soils Department of the Universidade Federal de Santa Maria, located in Santa MariaRS, Brazil ( $\left.29^{\circ} 42^{\prime} \mathrm{S}, 53^{\circ} 42^{\prime} \mathrm{W}\right)$. The main characteristics of the soils follow: $5.1 \mathrm{pH}_{\mathrm{H} 2 \mathrm{O}} ; 2.4 \%$ total $\mathrm{C} ; 0.22 \%$ total $\mathrm{N}$; $8.0 \mathrm{mg} \mathrm{NH}{ }^{+}-\mathrm{N} / \mathrm{kg} ; 19.9 \mathrm{mg} \mathrm{NO}{ }^{-}-\mathrm{N} /$ $\mathrm{kg} ; 13.8 \mathrm{CEC}\left(\mathrm{cmol}_{\mathrm{c}} / \mathrm{dm}^{3}\right) ; 38.7 \mathrm{mg}$ $\mathrm{dm}^{-3}$ P-Mehlich-I; $228.0 \mathrm{mg} \mathrm{dm}^{-3} \mathrm{~K}$; $5.7 \mathrm{cmol}_{\mathrm{c}} \mathrm{dm}^{-3} \mathrm{Ca} ; 2.5 \mathrm{cmol}_{\mathrm{c}} \mathrm{dm}^{-3} \mathrm{Mg}$; $50.9 \%$ clay; $21.5 \%$ silt and $27.6 \%$ sand for the Rhodic Hapludox (clayey soil); and $4.7 \mathrm{pH}_{\mathrm{H} 2 \mathrm{O}} ; 0.8 \%$ total $\mathrm{C} ; 0.08 \%$ total $\mathrm{N} ; 9.6 \mathrm{mg} \mathrm{NH}_{4}^{+}-\mathrm{N} / \mathrm{kg} ; 5.8 \mathrm{mg} \mathrm{NO}_{3}^{-}-\mathrm{N} /$ $\mathrm{kg} ; 7.6 \mathrm{CEC}\left(\mathrm{cmol}_{\mathrm{c}} / \mathrm{dm}^{3}\right) ; 33.8 \mathrm{mg} \mathrm{dm}^{-3}$ P-Mehlich-I; $81.3 \mathrm{mg} \mathrm{dm}^{-3} \mathrm{~K} ; 1.9 \mathrm{cmol}_{\mathrm{c}}$ $\mathrm{dm}^{-3} \mathrm{Ca} ; 0.6 \mathrm{cmol}_{\mathrm{c}} \mathrm{dm}^{-3} \mathrm{Mg} ; 10.7 \%$ clay; $29.6 \%$ silt and $59.8 \%$ sand for the
Typic Paleudalf (sandy-loam soil). The soils were gently crumbled, sieved at 4 $\mathrm{mm}$ and visible organic residues were manually removed.

The three compost treatments evaluated in this study were: 1) Pig slurry (PS) compost produced without additives to PS during composting (PS compost); 2) PS compost + retorted oil shale (ROS) produced with ROS addition to PS during composting (PS compost + ROS) and 3) PS compost + ROS + dicyandiamide (DCD) produced with ROS and DCD addition to PS during composting (PS compost + ROS + DCD). PS compost was made by mixing sawdust $(70 \%)$ and wood shavings (30\%) with PS in an automated composting for 245 days. The additives (ROS and DCD) were added 15 times with the PS to the piles, during 133 days of the automated composting to mitigate $\mathrm{NH}_{3}, \mathrm{CH}_{4}$ and $\mathrm{N}_{2} \mathrm{O}$ emissions (Giacomini, 2017). Total organic carbon (TOC) and nitrogen of the composts were determined by dry combustion in Flash EA 1112 Automatic Elemental Analyzer, while inorganic $\mathrm{N}$ content was determined according to Tedesco et al. (1995). The main characteristics of the composts are shown in Table 1.

This study was conducted during 58 days in a greenhouse (August 20, 2015 to October 17, 2015). The treatments consisted of two contrasting soils (sandy-loam and clayey), three types of composts (PS compost, PS compost + ROS and PS compost + ROS + DCD) and a control treatment for each soil texture (unamended soil), totaling eight treatments. The treatments were arranged as a completely randomized design with four replicates. In each experimental unit, dry clayey and sandyloam soils ( 5.5 and $6.5 \mathrm{~kg}$, respectively) were placed in an $8 \mathrm{~L}$ pot with 24 and $20.5 \mathrm{~cm}$ top and base diameters and $21 \mathrm{~cm}$ height. The composts were thoroughly mixed with the soil at 37.2 $\mathrm{g} / \mathrm{kg}$ of soil for PS compost, $90.2 \mathrm{~g} / \mathrm{kg}$ of soil for PS compost + ROS and 83.3 $\mathrm{g} / \mathrm{kg}$ of soil for PS compost + ROS + DCD. These doses were equivalent to an addition of $5.5 \mathrm{~g}$ total $\mathrm{N} /$ pot $(1.0 \mathrm{t}$ total $\mathrm{N} \mathrm{ha}^{-1}$ ) in the clayey soil and $6.5 \mathrm{~g}$ total $\mathrm{N} /$ pot $\left(1.4 \mathrm{t}\right.$ total $\left.\mathrm{N} \mathrm{ha}^{-1}\right)$ in the sandyloam soil. The compost doses were 
established according to $\mathrm{N}$ requirements of arugula (Eruca sativa) according to the technical local recommendation (CQFS-RS/SC, 2004) and assuming a mineralization index of $10 \%$ of total compost N (Cantú, 2014).

The arugula was selected due to its high $\mathrm{N}$ demand [100-180 $\mathrm{kg} \mathrm{N} \mathrm{ha}^{-1}$ (CQFS-RS/SC, 2004)] and the short vegetative cycle (30-40 days). Two plants were transplanted from tubes to each pot. Plants were grown in a controlled level of soil moisture $(80 \%$ of field capacity) in a greenhouse. Moisture was controlled by periodically weighing the pots and adding water when needed. The first cut of arugula was made 28 days after transplanting. Leaves were cut $6.0 \mathrm{~cm}$ from the soil surface to determine fresh matter and dry matter yields. The second cut was made 58 days after transplanting. At this time, the root production of arugula was also quantified. Leaves and roots were dried in forced air oven at $65^{\circ} \mathrm{C}$ during $24 \mathrm{~h}$ to determine dry matter yield. The dried tissues were ground in a ball mill and total $\mathrm{N}$ concentration was determined by dry combustion in CHNS Elemental Analyzer (ThermoFinnigan Flash EA 1112, Milan, Italy).

The accumulation of $\mathrm{N}$ by plants was calculated by multiplying leaf and root dry matter yield by $\mathrm{N}$ concentration of each constituent. Net $\mathrm{N}$ accumulation by arugula was calculated as the difference between the treatments that received $\mathrm{N}$ addition via composts and the unfertilized treatment (control). The apparent nitrogen recovery (ANR) with the composts by arugula in the first and second cuts was calculated according to the equation proposed by Craswell \& Godwin (1984):

$$
A N R=\frac{\text { Nuptake }_{F}-\text { Nuptake }_{C}}{\text { FertilizerNapplied }_{\text {Ner }}} \times 100^{\prime}
$$

where: ANR is the apparent $\mathrm{N}$ recovery $(\%)$; $\mathrm{N}$ uptake $\mathrm{F}_{\mathrm{F}}(\mathrm{mg} / \mathrm{pot})$ is the amount of $\mathrm{N}$ accumulated by the plants supplied with $\mathrm{N}$ fertilizer; $\mathrm{N}$ uptake ${ }_{\mathrm{C}}$ (mg/pot) is the amount of $\mathrm{N}$ absorbed by the plants in the unfertilized control; and Fertilizer $\mathrm{N}$ applied (mg/pot) is the $\mathrm{N}$ rate applied with the composts.

Fresh and dry matter yields and the amount of $\mathrm{N}$ uptaken by arugula were submitted to analysis of variance (ANOVA), considering the soil type, the composts and their interaction. The means between soils were compared by Tukey test at 5\% and within each soil by orthogonal contrasts, comparing the influence of the compost (Composts vs. Control), the influence of the additives (Compost without additives vs. Composts with additives) and the influence of DCD (Compost + ROS vs. Compost + ROS + DCD). The differences were considered significant at $\mathrm{p} \leq 0.05$.

\section{RESULTS AND DISCUSSION}

The differences in characteristics of the two soils influenced arugula yield, which was higher in the clayey soil. Leaf fresh matter yield in the control treatments was 2.2 times higher in the clayey soil than in the sandy-loam soil in the first cut and 8.0 times higher in the second cut (Table 2). This same trend was observed in leaf dry matter yield. The higher yield potential of arugula in the clayey soil is mainly associated to the total soil organic carbon (TOC), which was three times higher than that of the sandy-loam soil. Mineralization of soil organic $\mathrm{N}$ increased $\mathrm{N}$ availability, which can be observed in the amount of $\mathrm{N}$ accumulated in the leaves of the control treatment, which was 3.3 times higher in the clayey soil than in the sandy-loam soil in the first cut and 6.3 times in the second cut (Table 3). The higher nutrient content in the clayey soil than in the sandy-loam soil may also have favored arugula production, as found by Villas Bôas et al. (2004), who noted that biomass lettuce yield was directly related to soil TOC content.

The results showed a significant interaction between soils and composts, indicating that arugula responded differently to treatments, depending on soil type. The average leaf fresh and dry

Table 1. Characteristics of pig slurry (PS) composts (dry basis) and doses added to clayey and sandy-loam soils. Santa Maria, UFSM, 2015.

\begin{tabular}{|c|c|c|c|c|c|c|c|}
\hline \multirow{2}{*}{ Treatments } & DM & Total C & Total N & $\mathrm{NH}_{4}^{+}-\mathbf{N}$ & $\mathrm{NO}_{3}^{-}-\mathrm{N}$ & \multirow{2}{*}{$\mathbf{C} / \mathbf{N}$} & \multirow{2}{*}{ pH } \\
\hline & \multicolumn{5}{|c|}{$\left(\mathrm{g} \mathrm{kg}^{-1}\right)$} & & \\
\hline PS Compost & 335.0 & 378.4 & 26.9 & 0.41 & 0.022 & 14.1 & 6.6 \\
\hline PS Compost + ROS & 525.0 & 257.9 & 11.0 & 0.15 & 0.002 & 23.4 & 6.4 \\
\hline PS Compost + ROS + DCD & 522.0 & 231.9 & 12.0 & 0.17 & 0.001 & 19.3 & 7.8 \\
\hline \multirow{2}{*}{ Clayey soil } & \multicolumn{5}{|c|}{ Application dose } & & \\
\hline & \multicolumn{3}{|c|}{ (g/pot) } & \multicolumn{2}{|c|}{ (mg/pot) } & & \\
\hline PS Compost & 204.5 & 77.4 & 5.5 & 83.8 & 4.5 & & \\
\hline PS Compost + ROS & 500.0 & 129.0 & 5.5 & 75.0 & 1.0 & & \\
\hline PS Compost + ROS + DCD & 458.3 & 106.3 & 5.5 & 77.9 & 0.5 & & \\
\hline \multicolumn{6}{|l|}{ Sandy-loam soil } & & \\
\hline PS Compost & 241.7 & 91.4 & 6.5 & 99.1 & 5.3 & & \\
\hline PS Compost + ROS & 590.9 & 152.4 & 6.5 & 88.6 & 1.2 & & \\
\hline PS Compost + ROS + DCD & 541.6 & 125.6 & 6.5 & 92.1 & 0.6 & & \\
\hline
\end{tabular}

$\mathrm{DM}=$ dry matter; $\mathrm{ROS}=$ retorted oil shale $\mathrm{DCD}=$ dicyandiamide. 
matter yields in the treatments with the composts application increased by 4.3 and 4.9 times in the first cut in the sandyloam soil, while these increases were only 2.4 and 2.6 times in the clayey soil, respectively. Although arugula yields increased with addition of composts in both soils (Table 2, contrast A vs. B, C, $\mathrm{D})$, the best response observed in the sandy-loam soil was due to its lower nutrient supply capacity (especially N) as indicated by the low arugula yield in the control treatment. Thus, the results showed greater crop dependence on external nutrient supply in soils with lower organic matter content.

Among the three compost treatments (Table 3, contrast B vs. C, D), the best results in terms of $\mathrm{N}$ accumulation and fresh matter yield in both cuts and dry matter yield in the second cut were found in PS compost. One of the hypotheses to justify the average reduction of $30.5 \%$ in total dry matter yield of arugula in the two treatments with additives (PS compost + ROS and
PS compost + ROS + DCD) in relation to PS compost is the possible effect of ROS on reducing the mineralization of the two composts in soil. In the study of Leão et al. (2014), the addition of ROS to the soil reduced $\mathrm{C}$ mineralization of soybean crop residues. This suggests that due to its lamellar structure and high specific surface area (Pimentel et al., 2006), ROS can favor physical and chemical protection of soil organic matter (SOM) and the adsorption of labile $\mathrm{C}$, hindering its decomposition by soil microbial biomass (Doumer et al. 2011), however, more specific studies are necessary to confirm this hypothesis. If confirmed, this would indicate that although ROS reduces compost $\mathrm{N}$ availability, its use during composting would increase $\mathrm{C}$ retention in soil with the agricultural use of the compost as fertilizer.

The effect of DCD on arugula was found only in fresh matter yield of the second cut in both soils (Table 2, contrast $\mathrm{C}$ vs. D), where it increased the average yield by $27.5 \%$ (Table 2 ). Although dry matter yield of the second cut increased with the use of DCD in 33\% in the clayey soil and in $42 \%$ in the sandy-loam soil, these increases were not significant $(\mathrm{p}=0.07$ and $\mathrm{p}=0.06$, respectively). Table 3 shows that there was also an increasing trend in $\mathrm{N}$ availability to arugula in the second cut, where $\mathrm{N}$ accumulation increased by $56 \%$ in the clayey soil and $62 \%$ in the sandy-loam soil. The lower $\mathrm{C} / \mathrm{N}$ ratio of PS compost $+\mathrm{ROS}+\mathrm{DCD}$ compared to PS compost + ROS (19.3 vs. 23.4, Table 1) may have facilitated $\mathrm{N}$ decomposition and release to the soil of PS compost + ROS + DCD. Probably, the DCD addition during composting has reduced $\mathrm{N}$ losses by denitrification, which reduced the $\mathrm{C} / \mathrm{N}$ ratio of the final compost.

Nitrogen accumulation by arugula increased in treatments with compost addition (Table 3, contrast A vs. B, C, D) in both cuts and in both soils. The increase was greater in the treatment

Table 2. Fresh and dry matter yields of arugula after the application of pig slurry (PS) composts with and without the addition of retorted oil shale (ROS) and dicyandiamide (DCD) in clayey and sandy-loam soils. Santa Maria, UFSM, 2015.

\begin{tabular}{|c|c|c|c|c|c|c|c|}
\hline \multirow{3}{*}{ Treatments } & \multicolumn{3}{|c|}{ Fresh matter (g/pot) } & \multicolumn{4}{|c|}{ Dry matter (g/pot) } \\
\hline & \multirow{2}{*}{$\begin{array}{l}1^{\text {st }} \text { cut } \\
\text { Leaves }\end{array}$} & \multirow{2}{*}{$\begin{array}{l}2^{\text {nd }} \text { cut } \\
\text { Leaves }\end{array}$} & \multirow{2}{*}{ Total } & \multirow{2}{*}{$\begin{array}{l}1^{\text {st }} \text { cut } \\
\text { Leaves }\end{array}$} & \multicolumn{2}{|c|}{$2^{\text {nd }}$ cut } & \multirow{2}{*}{ Total } \\
\hline & & & & & Leaves & Roots & \\
\hline \multicolumn{8}{|l|}{ Clayey soil } \\
\hline Control (A) & $16.42 \mathrm{a}$ & 20.89 a & $37.31 \mathrm{a}$ & $1.21 \mathrm{a}$ & $1.40 \mathrm{a}$ & $0.38 \mathrm{a}$ & $2.99 \mathrm{a}$ \\
\hline PS Compost (B) & $44.17 \mathrm{a}$ & $36.40 \mathrm{a}$ & $80.57 \mathrm{a}$ & $3.38 \mathrm{a}$ & $2.74 \mathrm{a}$ & $0.60 \mathrm{a}$ & $6.72 \mathrm{a}$ \\
\hline PS Compost + ROS (C) & $37.97 \mathrm{a}$ & $15.10 \mathrm{a}$ & $53.08 \mathrm{a}$ & $3.09 \mathrm{a}$ & $1.08 \mathrm{a}$ & $0.56 \mathrm{a}$ & $4.73 \mathrm{a}$ \\
\hline PS Compost+ ROS + DCD (D) & $36.58 \mathrm{a}$ & $19.24 \mathrm{a}$ & $55.82 \mathrm{a}$ & $3.11 \mathrm{a}$ & $1.44 \mathrm{a}$ & $0.47 \mathrm{a}$ & $5.02 \mathrm{a}$ \\
\hline Contrasts & & & & (p value) & & & \\
\hline A vs. B, C, D & $<0.01$ & 0.04 & $<0.01$ & $<0.01$ & 0.03 & $<0.01$ & $<0.01$ \\
\hline B vs. C, D & $<0.01$ & $<0.01$ & $<0.01$ & 0.14 & $<0.01$ & $<0.01$ & $<0.01$ \\
\hline C vs. D & 0.19 & 0.01 & 0.07 & 0.94 & 0.07 & 0.01 & 0.26 \\
\hline \multicolumn{8}{|l|}{ Sandy-loam soil } \\
\hline Control (A) & $7.59 \mathrm{~b}$ & $2.60 \mathrm{~b}$ & $10.19 \mathrm{~b}$ & $0.48 \mathrm{~b}$ & $0.28 \mathrm{~b}$ & $0.06 \mathrm{~b}$ & $0.82 \mathrm{~b}$ \\
\hline PS Compost (B) & $43.48 \mathrm{a}$ & $23.40 \mathrm{~b}$ & $66.88 \mathrm{~b}$ & $2.98 \mathrm{a}$ & $1.79 \mathrm{~b}$ & $0.26 \mathrm{~b}$ & $5.03 \mathrm{~b}$ \\
\hline PS Compost + ROS (C) & $26.43 \mathrm{~b}$ & $11.83 \mathrm{~b}$ & $38.26 \mathrm{~b}$ & $1.99 \mathrm{~b}$ & $0.91 \mathrm{a}$ & $0.20 \mathrm{~b}$ & $3.10 \mathrm{~b}$ \\
\hline PS Compost+ ROS + DCD (D) & $27.76 \mathrm{~b}$ & $15.15 \mathrm{~b}$ & $42.91 \mathrm{~b}$ & $2.11 \mathrm{~b}$ & $1.29 \mathrm{a}$ & $0.18 \mathrm{~b}$ & $3.58 \mathrm{~b}$ \\
\hline Contrasts & & & & ( $p$ value $)$ & & & \\
\hline A vs. B, C, D & $<0.01$ & $<0.01$ & $<0.01$ & $<0.01$ & $<0.01$ & $<0.01$ & $<0.01$ \\
\hline B vs. C, D & $<0.01$ & $<0.01$ & $<0.01$ & $<0.01$ & $<0.01$ & 0.02 & $<0.01$ \\
\hline C vs. D & 0.21 & 0.03 & $<0.01$ & 0.57 & 0.06 & 0.66 & 0.07 \\
\hline
\end{tabular}

The letters in the columns compare same treatment between soils, according to Tukey test $(\mathrm{p} \leq 0.05)$. 
Table 3. Accumulation and apparent nitrogen recovery (ANR) by arugula after the application of pig slurry (PS) composts, with and without the addition of retorted oil shale (ROS), and dicyandiamide (DCD) to clayey and sandy-loam soils. Santa Maria, UFSM, 2015.

\begin{tabular}{|c|c|c|c|c|c|c|}
\hline \multirow{3}{*}{ Treatments } & \multicolumn{4}{|c|}{$\mathrm{N}$ accumulation (mg/pot) } & \multicolumn{2}{|c|}{ ANR } \\
\hline & \multirow{2}{*}{$\begin{array}{l}1^{\text {st }} \text { cut } \\
\text { Leaves }\end{array}$} & \multicolumn{2}{|c|}{$2^{\text {nd }}$ cut } & \multirow{2}{*}{ Total } & \multirow{2}{*}{$1^{\text {st }}$ cut } & \multirow{2}{*}{$2^{\text {nd }}$ cut $^{1}$} \\
\hline & & Leaves & Roots & & & \\
\hline \multicolumn{5}{|l|}{ Clayey soil } & \multicolumn{2}{|c|}{$(\%)$} \\
\hline Control (A) & $74.2 \mathrm{a}$ & $79.5 \mathrm{a}$ & $9.6 \mathrm{a}$ & $163.3 \mathrm{a}$ & - & - \\
\hline PS Compost (B) & $197.3 \mathrm{a}$ & $103.6 \mathrm{a}$ & $14.3 \mathrm{a}$ & $315.2 \mathrm{a}$ & $2.2 \mathrm{a}$ & $0.5 \mathrm{a}$ \\
\hline PS Compost + ROS (C) & $151.7 \mathrm{a}$ & $25.1 \mathrm{a}$ & $12.3 \mathrm{a}$ & $189.1 \mathrm{a}$ & $1.4 \mathrm{a}$ & $-0.9 b$ \\
\hline PS Compost + ROS + DCD (D) & $158.3 \mathrm{a}$ & $39.3 \mathrm{a}$ & $10.1 \mathrm{a}$ & $207.7 \mathrm{a}$ & $1.5 \mathrm{a}$ & $-0.7 \mathrm{~b}$ \\
\hline Contrasts & \multicolumn{6}{|c|}{ (p value $)$} \\
\hline A vs. B, C, D & $<0.01$ & $<0.01$ & $<0.01$ & $<0.01$ & - & - \\
\hline B vs. C, D & $<0.01$ & $<0.01$ & $<0.01$ & $<0.01$ & $<0.01$ & $<0.01$ \\
\hline C vs. D & 0.60 & 0.08 & 0.02 & 0.21 & 0.51 & 0.12 \\
\hline Sandy-loam soil & \multicolumn{4}{|c|}{$(\mathrm{mg} \mathrm{N} / \mathrm{pot})$} & \multicolumn{2}{|c|}{$(\%)$} \\
\hline Control (A) & $22.2 \mathrm{~b}$ & $12.6 \mathrm{~b}$ & $1.2 \mathrm{~b}$ & $36.0 \mathrm{~b}$ & - & - \\
\hline PS Compost (B) & $172.2 \mathrm{a}$ & $58.7 \mathrm{~b}$ & $7.1 \mathrm{~b}$ & $238.0 \mathrm{~b}$ & $2.3 \mathrm{a}$ & $0.8 \mathrm{a}$ \\
\hline PS Compost + ROS (C) & $87.5 \mathrm{~b}$ & $24.1 \mathrm{a}$ & $3.9 \mathrm{~b}$ & $115.5 \mathrm{~b}$ & $1.0 \mathrm{~b}$ & $0.2 \mathrm{a}$ \\
\hline PS Compost + ROS + DCD (D) & $89.5 \mathrm{~b}$ & $39.0 \mathrm{a}$ & $4.2 \mathrm{~b}$ & $132.7 \mathrm{~b}$ & $1.0 \mathrm{~b}$ & $0.5 \mathrm{a}$ \\
\hline Contrasts & \multicolumn{4}{|c|}{ ( $p$ value $)$} & & \\
\hline A vs. B, C, D & $<0.01$ & $<0.01$ & $<0.01$ & $<0.01$ & - & - \\
\hline B vs. C, D & $<0.01$ & $<0.01$ & $<0.01$ & $<0.01$ & $<0.01$ & $<0.01$ \\
\hline C vs. D & 0.87 & 0.07 & 0.72 & 0.24 & 0.88 & 0.09 \\
\hline
\end{tabular}

${ }^{1}$ Leaves + roots. Letters in the columns compare same treatments between soils, Tukey test $(\mathrm{p} \leq 0.05)$.

without additives (PS compost) than in those with the addition of ROS and DCD (Table 3, contrast B vs. C, D). The net $\mathrm{N}$ accumulation by arugula in the first cut was $123.1 \mathrm{mg} /$ pot in PS compost and $80.8 \mathrm{mg} /$ pot in the average of the treatments with additives in the clayey soil and 150.0 and $66.3 \mathrm{mg} /$ pot in the sandy-loam soil, respectively. The amounts of mineral $\mathrm{N}$ added were 88.3 $\mathrm{mg} /$ pot in PS compost and $77.2 \mathrm{mg} /$ pot in the average of treatments with additives in the clayey soil and 104.4 and $96.7 \mathrm{mg} /$ pot in the sandy-loam soil, respectively (Table 1 ). These results show that most of the $\mathrm{N}$ accumulated by arugula in the first cut was already in the mineral form in the composts when they were added to soil. In the second cut, only arugula of PS compost accumulated more $\mathrm{N}(24.1 \mathrm{mg} / \mathrm{pot})$ than in the control treatment in the clayey soil. In the sandy-loam soil, N accumulation by arugula of PS compost surpassed the control treatment in 46.1 $\mathrm{mg} /$ pot as well as the average of the two treatments with additives in $27.2 \mathrm{mg} /$ pot. It is likely that the decomposition and nitrogen release of the composts added to the sandy-loam soil were favored, increasing $\mathrm{N}$ availability to arugula in the second cut. In an incubation study by Nendel et al. (2004), N mineralization of organic composts was higher in soils with lower clay content. This occurred because the lower physical protection of sand compared to clay facilitated the access of the soil microorganisms to the composts.

Nitrogen accumulation by arugula of the control treatment in the clayey soil in the second cut was close to that found in the first cut. On the other hand, $\mathrm{N}$ accumulation in treatments with compost addition was lower in the second cut than in the first one. In the treatments with ROS and ROS + DCD, $\mathrm{N}$ accumulation was even lower than in the control treatment. In the sandyloam soil, $\mathrm{N}$ accumulation decreased in all treatments in the second cut. These results show the small residual effect of compost $\mathrm{N}$, in addition to the possibility of microbial immobilization of soil N when composts with ROS and ROS + DCD were added to the clayey soil. Giacomini (2017) found that the addition of ROS to PS reduced the decomposition rate of the mixture of PS with substrate during composting. According to Pimentel et al. (2006), ROS composition (mainly of minerals, quartz, feldspads, micas, in addition to pyrite and carbonates), promotes chemically and physically protection of organic carbon, reducing its availability to heterotrophic microorganisms. According to Cambardella et al. (2003), organic substrates that partially decompose due to sub-optimal conditions during the composting process can be degraded after compost incorporation into the soil. Therefore, it is likely that the decomposition of the composts with ROS continued after 
application to soil, favoring microbial immobilization of $\mathrm{N}$ and reducing availability to arugula in the second cut.

The apparent nitrogen recovery (ANR) by arugula with PS compost did not exceed $2.2 \%$ in the clayey soil and $2.3 \%$ in the sandy-loam soil in the first cut. In the second cut, only $0.5 \%$ of the $\mathrm{N}$ applied in this treatment was recovered by arugula in the clayey soil and $0.8 \%$ in the sandy-loam soil. In the study of Yang et al. (2004), the ANR by ryegrass with pig slurry compost application (795 kg total N/ha) was 3.3\% after 20 weeks of cultivation. In two successive crops of lettuce, Cantú (2014) found $12.7 \%$ ANR of the applied N $(500 \mathrm{~kg}$ $\mathrm{N} \mathrm{ha}^{-1}$ ) to soil via pig slurry compost which was produced through automated composting. These results show that in spite of the addition of high amounts of $\mathrm{N}$ through 15 applications of PS in 245 days of composting (Giacomini, 2017), the organic $\mathrm{N}$ of the compost was slowly mineralized after addition to soil. This confirms the results of studies that found a high proportion of organic carbon and nitrogen of composts being recalcitrant and resistant to microbial degradation (Cordovil et al., 2005; Ribeiro et al., 2010; Masunga et al., 2016). This aspect is not different in the compost of PS obtained through automated composting process.

The results of this study show that the exclusive use of the compost was able to sustain arugula yield only in the first cut, even at high doses. In crops where more than one cut is normally done, as is the case of arugula, nitrogen fertilization after the first cut is necessary, since the organic $\mathrm{N}$ mineralization of the compost is low. The use of ROS and ROS + DCD to reduce $\mathrm{N}$ losses during composting reduced the efficiency of the composts in supplying $\mathrm{N}$ to arugula.

\section{ACKNOWLEDGMENTS}

We thank the Conselho Nacional de Desenvolvimento Científico e Tecnológico (CNPq) and the Coordenação de Aperfeiçoamento de Pessoal de Nível Superior-(CAPES) for financial support.

\section{REFERENCES}

BARTHOD, J; RUMPEL, C; DIGNAC, MF. 2018. Composting with additives to improve organic amendments. A review. Agronomy for Sustainable Development 38: 1-17.

BERNAL, MP; SOMMER, SG; CHADWICK, D; QING, C; GUOXUE, L; MICHEL, FC. 2017. Current approaches and future trends in compost quality criteria for agronomic, environmental, and human health benefits. In: SPARKS, DL (ed). Advances in Agronomy. Cambridge: Academic Press. p.143-233.

CÁCERES, R; MALINSKA, K; MARFA, O. 2018. Nitrification within composting: A review. Waste Management 72: 119-137.

CAMBARDELLA, CA; RICHARD, TL; RUSSEL, A. 2003. Compost mineralization in soil as a function of composting process conditions. European Journal of Soil Biology 39: 117-127.

CANTÚ, RR. 2014. Acidificação de dejetos de suinos em compostagem automatizada: Emissões gasosas de nitrogênio e resposta da alface à aplicação do composto no solo. Santa Maria, RS. 92p. UFSM. (Ph. thesis).

COMISSÃODEQUÍMICAE FERTILIDADEDO SOLO - CQFS-RS/SC. 2004. Recomendações de adubação e calagem para os estados do Rio Grande do Sul e Santa Catarina. Porto Alegre: Sociedade Brasileira de Ciência do Solo. 400p.

CRASWELL, ET; GODWIN, DG. 1984. The efficiency of nitrogen fertilizers applied to cereals in different climates. In: TINKER, PB; LAUCHIL, A (eds). Advances in Plant Nutrition 1: 1-55.

CORDOVIL, CMDS; COUTINHO, J; GOSS, M; CABRAL, F. 2005. Potentially mineralizable nitrogen from organic materials applied to a sandy soil: fitting the one-pool exponential model. Soil Use and Management 21: 65-72.

CORDOVIL, CMDS; CABRAL, F; COUTINHO, J. 2007. Potential mineralization of nitrogen from organic wastes to ryegrass and wheat crops. Biosource Technology 98: 3265-3268.

DONEDA, A. 2014. A acidificação de dejetos líquidos de suínos afeta as emissões de amônia e gases de efeito estufa no processo de compostagem automatizada. Santa Maria: UFSM. 101p. (Ph. thesis).

DOUMER, ME; GIACOMINI, SJ; SILVEIRA, CAP; WEILER, DA; BASTOS, LM; FREITAS, LL. 2011. Atividade microbiana e enzimática em solo após a aplicação de xisto retortado. Pesquisa Agropecuária Brasileira 46: 15381546.

GIACOMINI, DA. 2017. Estratégias para mitigar as emissões de $\mathrm{NH}_{3}, \mathrm{~N}_{2} \mathrm{O}$ e $\mathrm{CH}_{4}$ em compostagem automatizada de dejetos líquidos de suínos. Santa Maria: UFSM. 82p. (Ph. thesis).

GIACOMINI, DA; AITA, C; PUJOL, SB; GIACOMINI, SJ; DONEDA, A; CANTÚ, RR; DESSBESELL, A; LÜDTKE, RC; SILVEIRA, CAP. 2014. Mitigação das emissões de amônia por zeólitas naturais durante a compostagem de dejetos de suínos. Pesquisa Agropecuária Brasileira 49: 521-530.
JIANG, T; MA, X; TANG, Q; YANG, J; LI, G; SCHUCHARDT, F. 2016. Combined use of nitrification inhibitor and struvite crystallization to reduce the $\mathrm{NH}_{3}$ and $\mathrm{N}_{2} \mathrm{O}$ emissions during composting. Bioresource Technology 217: 210-218.

LEÃO, RE; GIACOMINI, SJ; REDIN, M; SOUZA, EL; SILVEIRA, CAP. 2014. The addition of retorted oil shale increases carbon retention of plant residues in the soil. Pesquisa Agropecuária Brasileira 49: 818-822.

LUO, Y; LI, G; LUO, W; SCHUCHARDT, F; JIANG, T; XU, D. 2013. Effect of phosphogypsum and dicyandiamide as additives on $\mathrm{NH}_{3}, \mathrm{~N}_{2} \mathrm{O}$ and $\mathrm{CH}_{4}$ emissions during composting. Journal of Environmental Sciences 25: 1338-1345.

MASUNGA, RH; UZOKWE, VN; MLAY, PD; ODEH, I; SINGH, A; BUCHAN, D; NEVE, S. 2016. Nitrogen mineralization dynamics of different valuable organic amendments commonly used in agriculture. Applied Soil Ecology 101: 185-193.

NENDEL, C; REUTER, S; KUBIAK, R; NIEDER, R. 2004. Nitrogen mineralization from mature bio-waste compost in vineyard soils. I. Long-term laboratory incubation experiments. Journal of PLant Nutrition and Soil Science 167: 397-407.

O'CALLAGHAN, M; GERARD, EM; CARTER, PE; LARDNER, R; SARATHCHANDRA, U; BURCH, G; GHANI, A; BELL, N. 2010. Effect of the nitrification inhibitor dicyandiamide (DCD) on microbial communities in a pasture soil amended with bovine urine. Soil Biology and Biochemistry 42: 1425-1436.

OLIVEIRA, PAV. 2004. Tecnologias para o manejo de resíduos na produção de suínos: manual de boas práticas. Embrapa Suínos e Aves. Available: http://www.cnpsa.embrapa. $\mathrm{br} / \mathrm{sgc} / \mathrm{sgc}$ _publicacoes/publicacao_n3r85f3h. pdf. Accessed: August 9, 2018.

OLIVEIRA, PAV; HIGARASHI, MM. 2006. Unidade de compostagem para o tratamento dos dejetos de suínos. Embrapa Suínos e Aves. Available: www.embrapa.br/suinos-e-aves/ busca-de-publicacoes/-/publicacao/856117/ unidade-de-compostagem-para-o-tratamentodos-dejetos-de-suinos. Accessed: June, 11 2018.

PARIZOTTO, C; PANDOLFO, CM. 2009. Produção orgânica de alface e atributos de solo pela aplicação de composto de dejetos de suínos. Revista Brasileira de Agroecologia 4: 195-199.

PIMENTEL, PM; SILVA JR, CN; MELO, DMA; MELO, MAF; MALDONADO, G; HENRIQUE, DM. 2006. Caracterização e uso de xisto para adsorção de chumbo (II) em solução. Cerâmica 52: 194-199.

RIBEIRO, HM; FANGUEIRO, D; ALVES, F; VENTURA, R; COELHO, D; VASCONCELOS, E; CUNHA-QUEDA, C; COUTINHO, J; CABRAL, F. 2010. Nitrogen mineralization from as organically managed soil and nitrogen accumulation in lettuce. Journal of Plant Nutrition and Soil Science 173: 260-267.

SINGH, J; SAGGAR, S; GILTRAP, DL; BOLAN, 
NS. 2008. Decomposition of dicyandiamide (DCD) in three contrasting soils and its effect on nitrous oxide emission, soil respiratory activity, and microbial biomass - an incubation study. Australian Journal of Soil Research 46: 517-525.

SOIL SURVEY STAFF. 2014. Keys to soil taxonomy. Washington, USA: United States Department of Agriculture (USDA) and
Natural Resources Conservation Service (NRCS). 372p.

TEDESCO, MJ; GIANELLO, C; BISSANI, CA; BOHNEM, H; VOLKWEISS, SJ. 1995. Análise de Solo, Plantas e outros Materiais. Porto Alegre: UFRGS. 174p.

VILLAS BÔAS, RL; PASSOS, JC; FERNANDES, DM; BULL, LT; CEZAR, VRS; GOTO, R.
2004. Efeito de doses e tipos de compostos orgânicos na produção de alface em dois solos sob ambiente protegido. Horticultura Brasileira 22: 28-34.

YANG, XM; DRURY, CF; REYNOLDS, WD; TAN, CS. 2004. Nitrogen mineralization and uptake by ryegrass in a clay loam soil amended with composts or liquid pig manure. Canadian Journal of Soil Science 84: 11-17. 